University of Nebraska - Lincoln

DigitalCommons@University of Nebraska - Lincoln

Faculty Publications -- Department of English

English, Department of

1976

\title{
Homosexuals and the Death Penalty in Colonial America
}

Louis Crompton

University of Nebraska - Lincoln

Follow this and additional works at: https://digitalcommons.unl.edu/englishfacpubs

Part of the Christian Denominations and Sects Commons, Cultural History Commons, English Language and Literature Commons, Gender and Sexuality Commons, Politics and Social Change Commons, Public History Commons, Regional Sociology Commons, Social Control, Law, Crime, and Deviance Commons, and the United States History Commons

Crompton, Louis, "Homosexuals and the Death Penalty in Colonial America" (1976). Faculty Publications -Department of English. 60.

https://digitalcommons.unl.edu/englishfacpubs/60

This Article is brought to you for free and open access by the English, Department of at DigitalCommons@University of Nebraska - Lincoln. It has been accepted for inclusion in Faculty Publications -- Department of English by an authorized administrator of DigitalCommons@University of Nebraska - Lincoln. 


\title{
HOMOSEXUALS AND THE DEATH PENALTY IN COLONIAL AMERICA
}

Louis Crompton, Ph.D.

\begin{abstract}
This article traces the legislative history of statutes prescribing the death penalty for sodomy in 17th-century New England and in the other American colonies. New England and some middle colonies broke with English legal tradition by adopting explicitly biblical language. After the Revolution, Pennsylvania took the lead, in 1786, in dropping the death penalty.
\end{abstract}

As the nation prepares to celebrate the bicentennial of the Declaration of Independence, the question of the status of the homosexual in pre-Revolutionary America comes to mind. The Body of Liberties approved by the Colony of Massachusetts Bay in 1641 welcomed refugees seeking to escape "the Tiranny or oppression of their persecutors" or famines or wars. For several hundred years America was to serve as a haven for minorities threatened with religious or political persecution in other lands. What then did it offer the homosexual? Not, assuredly, liberty or the pursuit of happiness. Indeed, it appears that in 1776 male homosexuals in the original 13 colonies were universally subject to the death penalty, and that in earlier times, for a brief period in one colony, lesbians had been liable to the same punishment for relations with other women. The following essay is an attempt to trace the capital laws against homosexuals in these colonies from their origin in the first settlements until their abolition after the Revolution.

\section{COLONIAL LAWS AGAINST HOMOSEXUALITY}

The first English statute against homosexuality was placed on the books by Parliament in 1533, under Henry VIII. This law, which made it a capital felony for any person to "commit the detestable and

Dr. Crompton is Professor of English, University of Nebraska, Lincoln, Nebraska 68588. He wishes to acknowledge the assistance of Daylene Bennett, Larry Lackner, and Barbara Vincent in searching colonial codes. 
abominable vice of buggery with mankind or beast," was several times reenacted and repealed, and finally reinstated under Elizabeth in 1563 in a form that remained unchanged until 1861, when the death penalty was dropped for life imprisonment. The word "vice," the biblical term "abominable," and the theological expression "buggery" (from the "Bulgarian" heresy) all point to the religious background of the law, as does the treatment of the offense in Coke's Institutes, published early in the 17th century. Though Continental law, following canon law, regularly made lesbian acts capital crimes (as in the Constitutions of Charles V issued in 1532), English law was not interpreted as criminalizing these.

In America, the five pre-Revolutionary southern colonies, following the lead of Virginia, either regarded the English law as in force without incorporating it into their statutes or else, as in the case of South Carolina, adopted it verbatim. In the north, however, a special Puritan code developed that uniquely distinguished America's legal style (though not, in this case, the substance of the law) from that of England. It was the spirit of Calvin's Geneva, not of Westminster, that prevailed in the Puritan colonies as far as capital laws were concerned. Nowhere does this self-identification of the Puritans, in legal matters, with the Jews of the Old Testament show more clearly than in the opening lines of the preamble to Connecticut's Laws of 1672, which declared that "the Serious Consideration of the Necessity of the Establishment of wholesome LAWES, for the Regulating of each Body Politik; Hath enclined us mainly in Obedience unto JEHOVAH the Great Law-giver: Who hath been pleased to set down a Divine Platforme, not only of the Morall, but also of Judicial lawes, suitable for the people of Israel" (Brinley, 1865). The first American "code," if it can be called that, was a simple list of "Capitall offences lyable to death" drawn up in Plymouth Colony in 1636. These included treason, murder, witchcraft, arson, sodomy, rape, buggery (here denoting bestiality), and adultery.

In the same year the General Court of Massachusetts asked the Rev. John Cotton to draw up fundamental laws. Interestingly enough, Cotton proposed to place lesbianism on a par with male homosexuality as a capital offense. The English buggery statute had been taken to apply to anal relations between men, or between men and women, as well as relations of both with animals, but not relations between two women. No doubt this reflected the fact that the Old Testament prescribed the death penalty for male homosexuality but made no reference to lesbianism. On the other hand, church canonists interpreting the traditions of Roman law as they bore on sodomy regularly included lesbian acts as meriting capital punishment, and records exist of executions in France and Italy. Section 20 of Cotton's proposed list of capital crimes reads: "Unnatural filthiness, to be 
punished with death, whether sodomy, which is carnal fellowship of man with man, or woman with woman, or buggery, which is carnal fellowship of man or woman with beasts or fowls" (Staples, 1847, p. $35 n)$.

Cotton's suggestion, however, was not followed. Instead, the Bay Colony adopted in 1641 its famous Body of Laws and Liberties, which punished 12 capital crimes, among them sodomy. Once again, this legislation, which set a precedent in its language for several other states, made clear the Puritan determination to form a Bible Commonwealth and to bring their laws into line with the Old Testament. The Bay Colony, in making sodomy a capital crime, did not follow the English statute but instead adopted the language of Leviticus 20:13. Section 8 of the 1641 laws was thus a word-for-word translation of a Hebrew law more than 2,000 years old: "If any man lyeth with mankinde as he lyeth with a woman, both of them have committed abhomination, they both shall surely be put to death" (Whitmore, 1890 , p. 55). Astonishingly, this phraseology was to remain on the books of at least one American state-Connecticut-until some 46 years after the Declaration of Independence.

Some insight into Puritan thinking on these matters may be gleaned from an inquiry sent by Richard Bellingham, governor of the Bay Colony, to leading Massachusetts divines in 1642. Seeking guidance in the case of some men who had had sexual relations with young girls, Bellingham sought to determine if their offense constituted sodomy. William Bradford, who recorded the responses in his history of Plymouth Plantation, noted that sexual wickedness in New England was "much witnesed against, and ... narrowly looked into, and severly punished when it was knowne." Nevertheless, he reported, "Even sodomie and bugerie, (things fearfull to name,) have broak forth in this land, oftener then once" (Bradford, 1912, Vol. 2, p. 309). The copious and ingenious use of biblical analogies by Bellingham's correspondents was more in the spirit of the Talmud than of English courts. Like the Jews in Palestine, the Puritans in New England were convinced that their grasp on their new territory would be jeopardized if they provoked divine wrath by allowing sexual "abominations" to go unpunished. This is why Bradford thought of sodomy as such a "fearfull" sin. One correspondent made this plain by interpreting Leviticus 18:24, 25 to this effect: "The land is defiled by shuch sins, and spews out the inhabitants ... and that in regard of those nations that were not acquainted with the law of Moyses" (Bradford, 1912, Vol. 2, p. 323). Just as the Jews were concerned that their position in Palestine should not be forfeited by any reversion to the homosexual practices of the aboriginal Canaanites, so the Puritans were anxious that their claims in the New World should not be com- 
promised in God's eyes by failing to punish sexual criminals. In trying to understand 17th-century attitudes toward homosexuals we should not underestimate this primitive sense of terror and communal danger.

In 1648, the Body of Liberties was published as the Book of the General Laws and Liberties. In the one known remaining copy, Section 8 adds the clause "unles the one partie were forced (or be under fourteen years of age in which case he shall be severely punished)" (Laws and Liberties, 1929). New Plymouth, a separate colony, used this revised version of the 1641 Massachusetts Bay law in its code of 1671 . In 1697, after the union of the two colonies, the Massachusetts legislature, perhaps acting under pressure from the English government to bring its statutes more closely into line with those of England, passed "An Act for the Punishment of Buggery," which combined English and biblical language:

For avoiding of the detestable and abominable Sin of Buggery with Mankind or Beast, which is contrary to the very Light of Nature; Be it Enacted and Declared by the Lieutenant Governor, Council, and Representatives, in General Court assembled: and by the authority of the same it is Enacted, That the same Offence be adjudged Felony, and such Order and Form of Process therein be used against the Offenders, as in Cases of Felony: And that every Man, being duly convicted of lying with Mankind, as he lieth with a Woman: and every Man or Woman, that shall have carnal Copulation with any Beast or Brute Creature, the Offender and Offenders, in either of the Cases before mentioned, shall suffer the Pains of Death, and the Beast shall be slain and burnt. (Acts and Laws, 1724)

Subsequent to the Revolution, this law was reenacted in 1785 as "An Act against Sodomy," with the English legal phraseology removed but with the Levitical formula retained.

In 1635, Puritans from Massachusetts had established their first permanent settlement in Connecticut. A capital code introduced in 1642 copied the Bay Colony laws of 1641. These were later incorporated by Robert Ludlow into his Code of 1650. The Code of 1673 (the first to be printed) added the words "except it appear that one of the parties were forced, or under fifteen years of age" to the sodomy statute. This same capital law was reprinted with only slight verbal changes in the Acts and Laws of 1796 and again in the Laws of 1808, and remained on the books until 1822. In contrast to this conservatism was the New Haven law of 1655 published in New Haven's Settling in New-England and Some Lawes for Government. In the case of other capital crimes the New Haven code generally followed the style of the 1641 Body of Liberties. The sodomy statute, however, represented a unique and startling departure from New England tradition. The death penalty was extended to cover lesbianism, heterosexual anal intercourse, and even, in certain circumstances, masturbation: 
If any man lyeth with mankinde, as a man lyeth with a woman, both of them have committed abomination, they both shall surely be put to death. Levit. 20.13. And if any woman change the naturall use into that which is against nature, as Rom. 1. 26. she shall be liable to the same sentence, and punishment, or if any person, or persons, shall commit any other kinde of unnaturall and shamefull filthines, called in Scripture the going after strange flesh, or other flesh then God alloweth, by carnall knowledge of another vessel then God in nature hath appointed to become oneflesh, whether it be by abusing the contrary part of a grown woman, or child of either sex, or unripe vessel of a girle, wherein the natural use of the woman is left, which God hath ordained for the propagation of posterity, and Sodomiticall filthinesse (tending to the destruction of the race of mankind) is committed by a kind of rape, nature being forced, though the will were inticed, every such person shall be put to death. Or if any man shall act upon himself, and in the sight of others spill his owne seed, by example, or counsel, or both, corrupting or tempting others to doe the like, which tends to the sin of Sodomy, if it be not one kind of it; or shall defile, or corrupt himself and others, by any kind of sinfull filthinesse, he shall be punished according to the nature of the offence; or if the case considered with the aggravating circumstances, shall according to the mind of God revealed in his word require it, he shall be put to death, as the court of magistrates shall determine. (Trumbull, 1876, pp. 199-200)

One can only wonder what prompted this astonishing legislation, which had no parallel in colonial times. It remained in force for only 10 years, however, since in 1665 New Haven Colony joined Connecticut and came under Connecticut law.

In 1641, the New Hampshire towns united with the Bay Colony and became part of Massachusetts for 38 years. Then, in 1679, Governor John Cutt of New Hampshire had a capital code drawn up that copied the New Plymouth code of 1671 -the sodomy law was repeated identically. In 1718 the New Hampshire legislature passed "An Act against Murder, etc." consolidating capital laws and incorporating a sodomy law modeled on the Massachusetts statute of 1697. A law of 1792 echoed the Massachusetts law of 1785.

Rhode Island, by contrast, was alone among the northern colonies in not adopting, at any point, the language of Leviticus. A law appended to Roger Williams' charter in 1647 read as follows:

\section{Touching Whoremongers}

First of sodomy, which is forbidden by this present Assembly throughout the whole colony, and by sundry statutes of England. 25 Henry 8,6; 5 Eliz. 17. It is a vile affection, whereby men given up thereto leave the natural use of woman and burn in their lusts one toward another, and so men with men work that which is unseemly, as that Doctor of the Gentiles in his letter to the Romans once spake, $i .27$. The penalty concluded by that state under whose authority we are is felony of death without remedy. See 5 Eliz. 17. (Staples, 1847, pp. 31-32)

This statute is unique in finding its religious warrant in Saint Paul rather than in the Old Testament. In 1663 a more conventionally worded law was adopted: "And be it Enacted by the Authority aforesaid, That whosoever shall Perpetrate and commit the Detestable and Abominable Crimes of Sodomy or Buggery and be thereof Legally Convicted, shall suffer the Pains of Death; as in Cases of 
Felony, with benefit of Clergy" (Acts and Laws, 1719, p. 6). This is the form of the statute that appeared in the first published laws of Rhode Island in 1719.

The legislative picture in New York was complicated by military conquest and jurisdictional changes. New Amsterdam was under Dutch rule from 1613 till 1664, at which time the English took control. During this period the colony was liable to the Roman-Dutch law of Holland, which descended from Justinian and made homosexuality a capital offense. When Charles II granted the new English possessions to his brother, the so-called Duke of York's code was promulgated for Long island, Staten Island, and Westchester County in 1664, but did not go into effect until after the second Dutch occupation of 1673-1674. The force of the code was extended to the Delaware River in 1676. It is a curious fact that, despite the reaction against Puritanism at the Restoration and the Catholicism of James, the Duke of York's code was very much in the Puritan mold. It closely resembled both the 1641 Body of Liberties and the Connecticut Code of 1650 . The sodomy statute was, like theirs, Levitical: "If any man lyeth with mankind as he lyeth with a woman, they shall be put to Death, unless one party were Forced or be under fourteen Years of age, in which Case he shall be punished at the Discretion of the Court of Assizes" (Staughton et al., 1879, p. 14). Though the Duke of York's laws seem to have lapsed by 1691 , I can find no law on sodomy later than this among the laws of pre-Revolutionary New York. Presumably the colonists regarded the English statute as having force. After the Revolution, on February 14, 1787, the state legislature passed a law explicitly enforcing the death penalty.

So far the story of the status of the homosexual in colonial America has been unrelievedly grim. In Pennsylvania, however, Quaker humanitarianism promoted laws that looked forward to a happier, or at least, less-threatening, time. In 1676 the Duke of York's laws had been extended to include Pennsylvania. But when William Penn became proprietor, a new "Great Law" was promulgated on December 7,1682 , that was a landmark in Christian legislation. Because of the Quakers' aversion to the shedding of blood, this new code limited the death penalty to cases of murder and, for the first time, introduced prison sentences for other crimes. Though the early Quakers tended to deplore all nonmarital sexuality as culpable "licentiousness," they reduced the penalty for homosexual acts to 6 months' imprisonment, a lesser penalty than any American state would adopt until 1961. Chapter 9 of Penn's Quaker code provided that "if any person shall be Legally Convicted of the unnatural sin of Sodomy or joining with beasts, Such persons shall be whipt, and forfeit one third 
of his or her estate, and work six months in the house of Correction, at hard labour, and for the Second offence, imprisonment as aforesaid, during life" (Staughton et al., 1879, p. 110).

This abrogation of the death penalty lasted only till 1718 . The British Parliament objected to the substitution of affirmation for legal oaths, to which the Quakers were opposed. As a compromise, to keep affirmation, Pennsylvania was forced at that time to bring its code into line with Britain's. Over the years, however, there had been some erosion of the liberalism of 1682. On November 27, 1700, the assemly, in "An Act Against Incest, Sodomy, and Bestiality," required that "whosoever shall be legally convicted of sodomy or bestiality, shall suffer imprisonment during life and be whipped at the discretion of the magistrates, once every three months during the first year after conviction. And if he be a married man, he shall also suffer castration, and the injured wife shall have a divorce if required" (Mitchell \& Flanders, 1896, Vol. 2, p. 8). To the Quakers' shame, this is the only colonial law that enforced mutilation, a practice the Quakers usually viewed with distaste. Moreover, "An Act for the Trial of Negroes" of the same date made blacks liable to execution: "If any negro or negroes within this government shall commit a rape or ravishment upon any white woman or maid, or shall commit murder, buggery, or burglary, they shall be tried as aforesaid and shall be punished by death" (Mitchell \& Flanders, 1896, Vol. 2, p. 79).

Apparently the Quakers themselves reacted against the mutilation provision, for on January 12, 1705, a new "Act Against Sodomy and Buggery" dropped castration, though a companion bill reaffirmed the death penalty for blacks. Then, 13 years later, an act of May 31, 1718, "For the Advancement of Justice and More Certain Administration Thereof," declared that "if any person or persons shall commit sodomy or buggery, or rape or robbery... he or they ... shall suffer as felons, according to the tenor, direction, form and effect of the several statutes in such cases made and provided in Great Britain, any act or law of this province to the contrary notwithstanding" (Mitchell \& Flanders, 1896, Vol. 3, p. 202). So, for the time being, ended Pennsylvania's effort at law reform in sodomy cases.

Like Pennsylvania, Delaware and New Jersey were for a period under Quaker jurisdiction. Delaware passed from Dutch to English rule and was sold by the Duke of York to William Penn in 1683. From 1691 to 1704 it was united with Pennsylvania. In 1719 Delaware adopted the reactionary Pennsylvania measure of 1718 that accepted the English sodomy law. This statute was not superseded until the 19 th century.

In New Jersey the situation was more complex. West New Jersey 
was sold by the Duke of York to a proprietor, who sold it to the Quakers. The West New Jersey Quaker code, in force from 1681 until the union of West and East New Jersey in 1702, was silent on the subject of sodomy. East New Jersey was sold first to George Carteret. Carteret's codes of 1668 and 1675 took over verbatim the sodomy statute in the Duke of York's laws. When East New Jersey was also sold to the Quakers, a new code was introduced by Thomas Rudyard in 1683. Preston Edsall (1937) is of the opinion that under this code the only capital offenses were murder, bestiality, and false witness in capital cases. Section 9 of Rudyard's code said that "whoever shall lie with a beast shall be put to death." Usually, sodomy and bestiality were made capital offenses either under one law, as in England, or in successive statutes, as in the Puritan and ducal codes. However, the only reference to sodomy occurs in a very heterogeneous section (29) that directed that offenses as various as treason, murder, mayhem, cursing, drunkenness, stage plays, games, and bullbaitings should be "discouraged and punished by the Judges and Courts of Justice in this Province, according to the nature and kind of the said respective Offences" (Leamer \& Spicer, 1752, p. 239). Since murder, which was covered by this section, was treated as a capital offense, it is not impossible that sodomy may also have been. The intention is certainly obscure. After 1702 there appears to have been no sodomy law enacted in New Jersey until 1796, when a new criminal code added a noncapital statute.

Presumably, English law was regarded as in force in the province. This was certainly the case in the southern states, where the Puritan Levitical code was never adopted. Arthur Scott points out, in his Criminal Law in Colonial Virginia, that under this assumption trials were held and at least one execution for sodomy was carried out in Virginia. In Maryland, a Report of All Such English Statutes as Existed at the Time of the First Emigration of the People of Maryland, and which by Experience have been Found Applicable to their Local and Other Circumstances, issued in 1811 , listed 25 Henry 8,6 as an applicable statute, giving instances in which indictments were drawn under its form. Georgia seems to have proceeded similarly. An act of June 7, 1777, provided that "all the laws of England, as well statute as common, relative to criminal matters, and heretofore used and adopted in the courts of law in this state" should "be of full force" (Marbury \& Crawford, 1802, p. 400). A Collection of the Statutes of the Parliament of England in Force in North-Carolina published in 1792 lists 25 Henry 8, 6 and 5 Eliz. 17, and reprints both in full. Among the states south of Delaware, South Carolina seems to have been unique in that it actually wrote 25 Henry 8,6 verbatim into its own laws in 1712 , where it remained, death penalty and all, for 161 years (Cooper, 1837, p. 465). 


\section{ABOLITION OF THE DEATH PENALTY}

Eventually, of course, the tradition of making sodomy a capital offense came to an end. Reform came first, as one might have expected, in Pennsylvania. What made this change possible? The most significant influence seems to have been the success of the American Revolution. The Pennsylvanians had resented the imposition of the harsh British code in 1718 as an act of foreign tyranny. It was thus possible for reformers to represent the abolition of the death penalty as a return to a more humane native tradition. Indeed, the state constitution adopted by Pennsylvania in 1776 had specifically mandated "that the penal laws as heretofore used should be reformed by the legislature of this state as soon as may be and punishments made in some cases less sanguinary and in general more proportionate to the crimes." Accordingly, "An Act Amending the Penal Laws" was passed on September 15, 1786, with a provision that anyone convicted of "robbery, burglary, sodomy, or buggary" should suffer, not death, but the forfeit of all his lands and goods and servitude for a term "not exceeding ten years" (Mitchell \& Flanders, 1896, Vol. 12, pp. 280281).

During the post-Revolutionary period other states followed the lead of Pennsylvania whose code and penal practices provided a kind of national model (Barnes, 1926). But along with the native tradition of American Quakerism other influences were also making for a diminution of capital offenses. Montesquieu had noted that, as civilization advanced, criminal codes tended to be less draconic. His attitude toward homosexuality was a mixture of conservatism and liberalism. The Spirit of Laws, first published in 1748, devoted a chapter (Book 12, Section 6) to "The Crime Against Nature." He denounced homosexual acts as "infamous" offenses meriting "public horror." Nevertheless, he warned that sodomy prosecutions had been abused for political ends by tyrants. Moreover, he noted that in France only two other crimes were also punishable, like sodomy, by burning at the stake, namely, witchcraft and heresy. No doubt, by drawing attention to this fact Montesquieu meant to emphasize that these were all crimes of ecclesiastical origin that enlightened men would view skeptically. He made no specific recommendation for law reform, but the whole tenor of his chapter was toward a less lurid view than the traditional religious one.

Cesare Beccaria also discussed sodomy in his highly influential Crimes and Punishment in 1764. Chapter 31, "Crimes Difficult of Proof," grouped sodomy with adultery and infanticide. Like Montesquieu he was concerned with the possibility of unjust convictions. The law in Italy, he wrote, when punishing homosexuality, 
"employs tortures which often triumph over innocence itself." Beccaria believed that homosexuality was promoted by segregating boys in schools, and that society had no right to punish behavior it fostered through its educational system.

Not all jurists were so liberal. William Blackstone argued vehemently in his Commentaries in 1769 for the retention of capital punishment on religious grounds, citing the destruction of Sodom. Voltaire's Prix de la Justice et de l'Humanité, published in 1777 under Beccaria's inspiration, was less bloody-minded. In Article 19 ("De la Sodomie") Voltaire regretted that society should elect to burn a "few wretches." Sodomy, he suggested, was a crime that should be "shrouded by the shadows of oblivion, rather than illuminated by flaming faggots (les flammes desbuchers) in the eyes of the crowd." An unsigned editorial note to this chapter was explicit on the matter of law reform: "Sodomy, when there is no violence, should not come within the scope of the criminal law. It does not violate the right of any other man. It has only an indirect influence on the good order of society, like drunkenness or the love of gaming. It is a low, disgusting vice, whose true punishment is scorn. The penalty of burning is atrocious.... We must not forget to note that we owe this penalty to superstition" (Voltaire, 1785, p. 323n). In 1791 the French National Assembly dropped all reference to sodomy from the new Code Pénal of July 22, promulgated in the wake of the Declaration of the Rights of Man, which had maintained that "liberty consists in the power to do anything that does not injure others" and that "the law has the right to forbid only such actions as are injurious to society" (Anderson, 1967, p. 59).

In America Voltaire had, of course, little impact. Montesquieu, on the other hand, had an immense influence on American legislation, and Beccaria was widely read and studied. Beccaria opposed the death penalty and favored making punishments more "proportional" to the crimes that occasioned them. This idea of proportionality seems to have had a somewhat bizarre influence on Thomas Jefferson. When Jefferson began work with a committee to reform the criminal code of Virginia, he proposed, in his manuscript outline for a "Bill Proportioning Crimes and Punishments," a number of penalties that would certainly be excluded under the article in the Bill of Rights forbidding "cruel and unusual punishments." Poisoners were to be poisoned, and maimers maimed, and rapists and sodomites were to be castrated (Jefferson, 1950, Vol. 2, p. 664). Jefferson's views seem to have prevailed with the committee, for the bill that it reported on June 18, 1779, stated that "whosoever shall be guilty of Rape, Polygamy, or Sodomy, with man or woman, shall be punished, if a man, with castration, if a woman, by cutting thro' the cartilage of her 
nose a hole of one half inch diameter at the least" (p. 497). Was Jefferson breaking with Anglo-Saxon tradition by making lesbian relations a crime? One of the authorities quoted in a note to this section of the proposed bill defined "sodomitry" as "carnal copulation against nature, to wit of man or woman in the same sex, or of either of them with beasts." At this point, of course, Virginia had no sodomy statute on its books. However, the Virginia legislature never adopted Jefferson's bill. When a new Revised Code was issued on December 10, 1792, sodomy was made a capital offense "without benefit of clergy," that is, carrying a mandatory death sentence.

Nevertheless, reform slowly took place throughout the 13 original colonies. On March 18, 1796, New Jersey passed "An Act for the Punishment of Crimes" that made anyone convicted of sodomy liable to "a fine and solitary confinement at hard labor for any term not exceeding twenty-one years." Eight days later, New York passed "An Act Making Alterations in the Criminal Law" that retained the death penalty for treason and murder but decreed that any person convicted of any other offense formerly capital should instead be punished by life imprisonment. Rhode Island's Public Laws of 1798 provided "that every person who shall be convicted of sodomy... shall, for the first offence, be carried to the gallows in a cart, and set upon the said gallows, for a space of time not exceeding four hours, and thence to the common gaol, there to be confined for a term not exceeding three years, and shall be grievously fined at the discretion of the Court; and for the second offence shall suffer death." In England at this time exposure of homosexuals in the pillory was accompanied by public stoning, occasionally to the point of death.

In 1800, Virginia repealed its sodomy statute of 1792 by decreeing that anyone found guilty of any felony (not among those specifically excluded) formerly punishable by death without benefit of clergy should henceforth be confined to prison for a period of "not less than one nor more than ten years." Slaves, however, still remained liable to execution. In 1805, Massachusetts' "Act against Sodomy and Bestiality" made the penalty for these crimes imprisonment "not exceeding ten years." Maryland and New Hampshire made the penalty 1 to 10 years in 1809 and 1812, respectively, but Section 36 of Georgia's Penal Code of 1816 called for life imprisonment. Delaware's Code of 1826 set the punishment for sodomy at "solitary confinement for any term not exceeding three years," and a public whipping "with sixty lashes on the bare back well laid on" (Laws, 1829, p. 139).

By far the most conservative of the first 13 colonies were the Carolinas. North Carolina's Revised Code of 1855 kept the death penalty, and it was not until 1869 that the punishment for sodomy and other formerly capital crimes was made 5 to 60 years' imprison- 
ment. Slowest of all to act was South Carolina, where 25 Henry 8, 6 remained unrepealed until 1873, 12 years after England had dropped the capital provision. The new penalty in South Carolina was imprisonment for up to 5 years.

Thus the threat of the death penalty that had hung over the heads of America's homosexuals for more than 2 centuries came to an end. Were these laws ever enforced? I know of only two certain executions in English-speaking America. The first was the case of William Cornish in Virginia in 1625. (A transcription of the trial proceedings and the aftermath of bitter recriminations is reprinted at the end of this essay.) The second was the hanging of William Plain at Guilford in 1646 (Winthrop, 1853, p. 324). In Dutch New Amsterdam, two men were respectively condemned to be burned at the stake and drowned for relations with boys in 1646 and 1660 (O'Callaghan, 1968, pp. 103, 213). In 1793, William Bradford, attorney-general of Pennsylvania, published statistical tables that show that one man was executed for the "crime against nature" in the state as late as 1785 , but there is no indication as to wheter the case involved homosexuality or bestiality, both of which were punishable under the same statute (Montagu, 1809, p. 267).

Whether other executions took place we will not know until a search has been made through hundreds of local trial records. While historical research has provided ample documentation about executions for such "crimes" as witchcraft and heresy, information about the killing of homosexuals is, for most countries, scanty or nonexistent. The religious taboo that had, for more than a thousand years, made homosexuality something it was "not profitable to know," "the crime not fit to be named among Christian men," or, as Blackstone put it, a crime "the very mention of which is a disgrace to human nature," has severely inhibited historical and legal scholarship.

This is one of the ways in which the history of homosexual men and women in America contrasts with the history of other minorities. Another is the sheer enormity of the threat of genocide. In 1776, blacks certainly lacked the right to liberty and the pursuit of happiness, but not to life. American Indians lost their lands and faced what must have looked at times like a campaign of extermination, but this was not a policy officially sanctioned by the statute books. The status of the homosexual was more like that of certain religious minorities-Catholic priests for instance-whose mere presence in certain colonies made them liable to execution. But unlike religious minorities, homosexuals formed no organized communities, published nothing, had no supportive family traditions, found no asylums in any country in Christendom, and formed no colonies with their fellows. America's capital laws must have created a psychological 
reign of terror for the homosexual in the 17 th and 18 th centuries. Discrimination could be justified by pointing to the death penalty as a sign of the intensity of society's disapprobation. Presumably, few homosexuals emigrated to America with Puritan settlers. But there is no reason to suppose that America's first colonists had fewer homosexual sons and daughters than any other group. For these young people, "growing up gay" in the land of the free must have been a brutalizing experience.

\section{REFERENCES}

Acts and laws of his majesties colony of Rhode-Island. Boston: Nicholas Boone, 1719.

Acts and laws, passed by the great and general council or assembly of the province of Massachusetts-Bay in New-England from 1692, to 1719. London: J. Baskett, 1724.

Anderson, F. M. (Ed.). The constitutions and other select documents illustrative of the history of France (2nd ed.). New York: Russell \& Russell, 1967.

Barnes, H. E. The repression of crime. New York: George H. Doran, 1926.

Bradford, W. History of Plymouth Plantation (W. C. Ford, Ed., Vol. 2). Boston: Houghton Mifflin, 1912.

Brinley, G. The laws of Connecticut: an exact reprint of the original edition of 1673. Hartford: Privately printed, 1865.

Cooper, T. (Ed.). The statutes at large of South Carolina (Vol. 2). Columbia: A. S. Johnston, 1837.

Edsall, P. W. (Ed.). Journal of the courts of common right and chancery of East New Jersey 1683-1702. Philadelphia: American Legal History Society, 1937.

Jefferson, T. The papers of Thomas Jefferson (J. P. Boyd, Ed., Vol. 2). Princeton: Princeton University Press, 1950.

The laws and liberties of Massachusetts reprinted from the copy of the 1648 edition in the Henry E. Huntingdon Library. Cambridge: Harvard University Press, 1929.

Laws of the state of Delaware: Revised edition. Wilmington: R. Porter, 1829.

Leaming, A., \& Spicer, J. (Eds.). The grants, concessions, and original constitutions of the province of New-Jersey. Philadelphia: W. Bradford [1752].

Marbury, H., \& Crawford, W. (Eds.). Digest of the laws of the state of Georgia. Savannah: Seymour, Woolhopter \& Stebbins, 1802.

Mitchell, J. T., \& Flanders, H. (Eds.). The statutes at large of Pennsylvania from 1682 to 1801 (Vols. 2, 3, 12). Harrisburg: Clarence Busch, 1896.

Montagu, B. (Ed.). The opinions of different authors upon the punishment of death. London: Longman, Hurst, Rees \& Orme, 1809.

O'Callaghan, E. (Ed.). Calendar of Dutch historical manuscripts in the office of the secretary of state, Albany, New York 1630-1664. Ridgewood, N.J.: Gregg Press, 1968.

Staples, W. R. (Ed.). Proceedings of the first general assembly of the incorporation of Providence Plantation and the code of laws adopted in 1647. Providence: Charles Burnett, 1847.

Staughton, G., et al. Charter of William Penn and laws of the commonwealth of Pennsylvania ... preceded by Duke of York's laws. Harrisburg: Lane S. Hart, 1879.

Trumbull, J. H. The true-blue laws of Connecticut and New Haven. Hartford: American Publishing Co., 1876.

Voltaire. Oeuvres complètes (Vol. 29). L'Imprimerie de la Société LittéraireTypographique, 1785 .

Whitmore, W. (Ed.). The colonial laws of Massachusetts reprinted from the edition of 
1672 ... together with the Body of Liberties of 1641. Boston: Rockwell \& Churchill, 1890

Winthrop, J. The history of New England. (Vol. 2). Boston: Little, Brown, and Company, 1853.

\begin{abstract}
APPENDIX
The following items seemed of such potential interest to historians that we have included them as an appendix to Dr. Crompton's paper. The first, the Minutes of the Council and General Court of Colonial Virginia 1622-1632, 1670-1676, edited by H. R. McIlwaine (reprinted by permission of the Library Board of the Virginia State Library) gives a partial account of the trial that sent a man to his death for sodomy in 1624. The second item is from The Papers of Thomas Jefferson, Vol. 2, January 1777June 1779, edited by Julian P. Boyd (reprinted by permission of Princeton University Press). In it Jefferson suggests a lowering of the penalty for sodomy from death to castration.
\end{abstract}

\title{
The Execution of William Cornish
}

Following is an account of the trial of William Cornish for sodomy and the prosecutions that stemmed from it. The record shows that the Governor of Virginia, Sir Francis Wyatt, presided over all sessions of the court.

William Coufe aged 29 yeeres or therabouts fworne and examined fayeth, $\mathrm{y}^{\mathrm{t}} \mathrm{y}^{\mathrm{e}}$ xxvii th day of $A$ wguft laft paft about one or 2 of the Clock in ye afternoon, beinge aboord ye good fhipp called the Ambrofe then Ridinge at Anchor in James River Richard Williams als Cornufhe $\mathrm{M}^{\mathrm{r}}$ of the faid Shipp called the Ambrofe, beinge then in drinke Called to this Examinat, to lay A Cleane payre of theete into his bed, wch this Exam did, And the faid $W^{m}$ went into the bed, and wold have this Exam com into $y^{e}$ bed to him, wh this Exam refufinge to doe the faid Richard Williams went owt of the bed and did cut this Exam Cod peece . . ., and made this Exam unredy, and made him goe into $y^{e}$ bed and then ye faid Williams als Cornufh went into $\mathrm{y}^{\mathrm{e}}$ bed to him, and there lay Vppon him, and kift him and hugd him, fayinge that he wold love this exam yf he would now and then come and lay $w^{\text {th }}$ him and fo by force he turned this exam uppon his belly, And foe did putt this Exam to payne in the fundement and did wett him and after did cale for $A$ napkin $w^{\text {ch }}$ this Ex. did bringe vnto him, and fayeth that there was but one man A boarde the Thipp, w $^{\text {ch }}$ was Walter Mathew the boatfwains mate beinge . . . And further fayeth $y^{t}$ he was fore 3 or 4 dyes a[fter] and that after this ye next dye after in ye morning [the] faid Williams als Cornifh faid to this Exam though [ $I$ did] playe the foole $w^{\text {th }}$ you yefterdye, make no woondr further he layeth $\mathrm{y}^{t}$ after this many tymes he wou[ld] putt his hands in this Exam Cod peece and plaid a[nd] kifte him, faying to this Exam̃ $y^{t}$ he could have brought them to fea $w^{\text {th }}$ him, yf he had . . . him, that would have plaid $w^{\text {th }}$ him, And after this Exam beinge caled and refufinge to go he . . . him before the mafte and forbad all the fhipps Company to eate w $^{\text {th }}$ him, and mad this Exam Cooke for all the reft

Nov. 30, 1624

Walter Mathew fworne and Examined fayeth that beinge in the ftorage Roome in $W^{m}$ Cowfe his Caben, the $\mathrm{M}^{r}$ Caled the boy into his bed Cabin both beinge lockt in the great Cabin, between which and the boys Cabin there was a particon of deale boards into this Cabin, to $w^{\text {ch }} W^{m}$ Cowfe replied that he would not fayinge further that yf he 
did foe it would be an overthrow to him both in foule and bodye and aleged the scripture to him, but of what it was that the $\mathrm{M}^{\mathrm{r}}$ did urge him to he knoweth not, nor hard not the boy cry owt for help after this, this Examt went foorth of his Cabin vppon the deck and harde noe more, but when $W^{m}$ Cowfe cam foorth of the Cabin this Exã asked him $\mathbf{w}^{\mathrm{t}}$ the matter was between the $\mathrm{M}^{\mathrm{r}}$ and him to whom he replied he would keepe that to himfelf till he cam into England but after told this Examãt the $\mathbf{M}^{r}$ would have Bugard him or to that effect, but did not confers that the $\mathbf{M}^{\mathrm{r}}$ did the fact.

Jan. $3,1624 / 5$

Nicholas Roe fworne and Examined layeth $\mathrm{y}^{\mathrm{t}}$ he remembreth at Canada, $\mathrm{y}^{\mathrm{t}}$

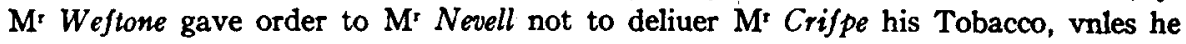
brought $\mathrm{M}^{r}$ Wetheredge to give fecuritie $\mathrm{y}^{t} \mathrm{M}^{r}$ Crifp fhould not Truck away any of his Tobacco in $\mathrm{y}^{\mathbf{e}}$ Country, but wether $\mathrm{M}^{\mathrm{r}}$ Weftone did abfolutely demande $\mathrm{M}^{\mathbf{r}}$ Wetheredge fhould give his bonde or to deliver it vppon his word this deponent doth not well remember

And further he fayeth that being at Dambrells Cove Jefferey Cornifh came abourd the fhip caled ye Swan and demanded this deponent, the caufe of his brothers executione fayinge $y^{t}$ [he] hath been told his brother was put to death wrongfully and $y^{t}$ he wold be revenged of them $y^{t}$ were $y^{e}$ occafion of it.

And further fayeth $\mathrm{y}^{\mathrm{t}}$ whilft Jeffery Cornifh and this examnate were in talke, $\mathrm{M}^{*}$ Nevell cam in place and told $\mathrm{y}^{\mathrm{e}}$ laid Jeffery Cornifh $\mathrm{y}^{\mathrm{t}}$ he was at the tryall of his brother, and at his executione alfo, and that he could fay more concerninge his execution then this deponent could doe, after $w^{\text {ch }}$ this deponent was cald down into $y^{e}$ hold, fo $\mathrm{y}^{\mathrm{t}} \mathrm{w}^{\mathrm{t}}$ other Converfation was betwixt them concerninge that, (he knoweth not The faid Cornifh and Nevell remayninge vppon the deck talkinge together, and more he cannot depofe,

John Giles fworne and examined fayeth, $\mathrm{y}^{\mathrm{t}}$ he hard Jeffery Cornifh fwere and faie that he wold be the caufe of the death of thole $y^{t}$ were $y^{e}$ caufe of putting his brother to death, This deponent beinge abourde their owne Thipp caled the Swann, And coming abourd another fhipp ridinge hard by, but $y^{t}$ Edward Nevell or another told ye faid Cornifh he was put to death wrongfully, he cannot lay

Chriftopher Knollinge fworne and examined fayeth, that being a fhore at Dambrells Cove in Canada Jeffery Cornifh cam vnto him, and demanded of him $\mathrm{w}^{\mathrm{t}}$ he could fay concerning his brother beinge put to death, fayinge that fome of ye Swan fhould tell him $y^{t}$ his brother was put to death wrongfully \& faid $\mathrm{y}^{t}$ he would fpend his blood for his brother to bee revenged of them $\mathrm{y}^{t}$ did it, but this deponent askinge the faid Cornifh who told him foe, he refured to tell him, and more he cannot fay.

Nicholes Hodges fworne and examined fayeth $\mathrm{y}^{\mathrm{t}}$ he harde $\mathrm{M}^{\mathrm{r}}$ Weftone fay to Nicholes Roe at Canada $\mathrm{y}^{\mathrm{t}}$ vnles he would figne a releafe vnto him, hee would putt his two men afhore, and would nott bringe them to Virginia

Dec. 5,1625

William ffofter fworne and Examined fayeth, that he this deponent demanded of $M^{*}$ Nevell at Canada beinge abord the fwann, wherfor $M^{*}$ Cornifhe was hanngd, vnto whom nevell anfwered and faide he was hangd for a rafcally boye wrongfully, And that he hath hard $\mathrm{Mr}$ nevell fay foe divers tymes

Dec. 12,1625

Thomas Crifpe gent by the oath he hath formerly taken affirmeth $\mathrm{y}^{\mathrm{t}}$ Jefferey Cornifhe did fay $\mathrm{y}^{\mathrm{t}}$ Edwa: Nevell fhuld tell him $\mathrm{y}^{\mathrm{t}}$ his brother fuffered death wrongfully, and the faid Thomas Crifpe wyfhed the faid Jeffery Cornifh to take heede $\mathrm{w}^{\mathrm{t}}$ he faide, :or fure the Gouernor would do noe wronge or iniultice to any man, for $y^{t}$ he fhalbe infwerable for $\mathrm{w}^{t}$ he doth. Thervppon the faid Jeffery Cornifh did vow, $\mathrm{y}^{t}$ he would be he death of the Gouernor yf ever he came for England.

Dec. 19,1625 
Arthur Avelinge fworne and examd fayeth, That be beinge at Damrells Cove in Canada abourde the fwan, one who came abourde asked $\mathrm{M}^{\mathrm{r}}$ nevell wherefore $\mathrm{M}^{\mathrm{r}}$ Cornifh was put to death Then Edward nevell aniwered he was put to death through a fourvie boys meanes, $\&$ no other came againft him Then the other man replied I have ill luck my brother fhuld come to fuch an end

$Y t$ is ordered $y^{t}$ Edward nevell for his offenc thall ftand one $y^{t}$ pillory $w^{\text {th }}$ a paper one his head thewinge the caure of his offence in the markett place, and to loofe both his Ears and to ferve the Colony for A yeere, And forever to be incapable to be A ffreeman of the Countrey

$$
\text { Jan. } 3,1625 / 6
$$

James Hickmote fworne and Examined fayeth, $\mathrm{y}^{t}$ one faterday night beinge the fowerth of ffebruary 1625 beinge at the howfe of Edward ffifher in James Cyttie, one Peter marten beinge in Compeny and fallinge in talke concerninge Richard Williams als Cornifh that was executed for Buggerie, The faid marten then Commendinge the faid Cornifh for an excellant mariner and skillfull Artift, Thomas hatch beinge alfo in compeny, faid that in his confyence he thought the faid Cornifhe was put to death wrongfully, whervppon this deponent faid, (you were beft take heede wi you faye, you have a pifident [precedent] before your eyes the other dye, And it will coft you yor eares yf you vfe fuch woordes, To $w^{\text {ch }}$ the faid Tho: hatch replied, I care not for my eares, lett them hange me yf they will

Sara fifher $\mathrm{y}^{e}$ wiefe of Edward fifher fworne and examined Affirmeth as much as Mr James hickmote hath vppon his oath formerly deliuered.

Anthony Jonnes fworne and Examined layeth, that he hard Thomas hatch fay that Richard Cornifh was putt to death wrongfully, and that he did not care for his eares

$Y^{\prime}$ is ordered $\mathrm{y}^{t}$. Thomas Hatch for his offence fhalbe whipt from the forte to the gallows and from thence be whipt back againe, and be fett vppon the Pillory and there to loofe one of his eares, And that his fervice to $\mathrm{S}^{r}$ : George Yardley for feaven yeers Shalbegain from the plent dye, Accordinge to the Condicion of the dewtie boyes he beinge one of them.

Feb. $6,1625 / 6$

\section{Proportioning of Crimes and Punishments}

The following is Thomas Jefferson's outline for his Bill for Proportioning Crimes and Punishments, written in 1777 .*

I. Crimes whose punishmt. extends to Life.

1. High-treason. Death 〈by burying alive qu. $\rangle$ by hanging

Forfeiture of lands \& goods to Commwth.

2. Petty Treason. Death by hanging.

Dissection.

Forfeitr of half lands \& goods to representatives of person killed.

3. Murder. 1. by poyson. Death by poyson.

2. in Duel. Dorfeitre. of one hath by hanging

gibbeting, if the challenger.

Forfeitre. of one half as before unless the Challengr fell, then to Commw.

*From The Papers of Thomas Jefferson, edited by Julian P. Boyd, Vol. 2, January 1777 to June 1779, pp. 663-664. Copyright 1950 by Princeton University Press. Reprinted by permission of Princeton University Press. 
3. any other way. Death by hanging

Forfeitre of half as before.

4. Manslaur. 2d offence is murder.

$$
\begin{aligned}
& \text { (1st. Labor } 7 \text { years.) } \\
& \text { (Forfeitre one half as before.) }
\end{aligned}
$$

II. Crimes whose punishment goes to Limb.
1. Rape.
(2. Polygamy) Castration.
2. Sodomy.
3. Maiming Retaliation.
4. Disfiguring $\}$ Forfeiture of half to sufferer.

III. Crimes punisheable by Labor \&c.

1. Manslaur. 1st. offence. Labor VII. years.

2. Counterfeiting. Labor VI. years.

Forfeitre. of half as before.

3. Arson. $\}\{$ Labor V. years.

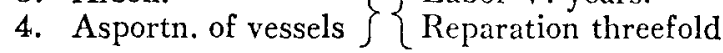

5. Robbery Labor IV. years

6. Burglary \}Reparation. double.

7. Housebreaking. Labor III. years

8. Horse-stealing \} Reparation.

9. Grand Larceny. Labor II. years

Reparation

10. Petty Larceny. Labor I. year.

Reparation

11. Witchcraft \&c.

(15. stripes. $\rangle$ pillory $1 / 4$ of an hour

Ducking

15. stripes.

12. Excusable homicide. 〈hcad $\sigma^{2}$ half the beard shaved a year.

13. Suicide. nothing.

14. Anothing.

$\mathrm{N}$ (DLC); entirely in TJ's hand, written in a long, narrow column. This document is presented as literally as possible. The italicized words (except those in angle brackets) represent words written by $T J$ in a hand resembling print, a device he frequently used for emphasis.

TJ later employed this list in preparing Query xrV of the Notes on Virginia, copying it almost verbatim in his discussion of the revised code (Ford, III,
250-1). Compare this outline also with the section on crimes and punishments in the Plan $\Lambda$ greed upon by the Revisors at Fredericksburg (Document $I$ in this series) and Bill No. 64. 